\title{
The Effect of Vocal Rehearsal on Retrieval of New Phonological Representations in Children with and without Specific Language Impairment
}

\author{
Eun-Joo Ryu ${ }^{a}$, Ji-Wan Haa, \\ aDepartment of Speech \& Language Pathology, Graduate School of Rehabilitation Science, Daegu University, Gyeongsan, Korea \\ ${ }^{b}$ Department of Speech \& Language Pathology, Daegu University, Gyeongsan, Korea
}

Correspondence: Ji-Wan $\mathrm{Ha}, \mathrm{PhD}$

Department of Speech Pathology, Daegu

University, 201 Daegudae-ro, Jillyang-eup,

Gyeongsan 38453, Korea

Tel: $+82-53-850-4327$

Fax: +82-53-850-4329

E-mail: jw-ha@daegu.ac.kr

Received: October 5, 2016

Revised: November 11, 2016

Accepted: November 21, 2016

This work was supported by the Daegu University Research Grant 2014 (20140304).

\begin{abstract}
Objectives: This research aims to study the ability to retain and retrieve new phonological representations (PR) with and without vocal rehearsals in children with specific language impairments (SLI) and typically developing (TD) children. Methods: Ten SLI children, 10 chronological age (CA)-matched children and 10 language age (LA)-matched children participated in the research. To compare the three groups' performance in terms of accuracy and error types, this test set time intervals of 10 seconds and 5 minutes; one with vocal rehearsal and one without vocal rehearsal after a lapse of time. The relationship among the new PR task performances and receptive vocabulary, and expressive vocabulary were examined. Results: SLI group showed significantly lower ability in retrieving new PR than CA group but were similar to LA group. The performance with vocal rehearsal was not significantly better than that without vocal rehearsal after 10 seconds but it was significantly better after 5 minutes. SLI group showed significantly more error types such as syllable omission, lexicalization and no response when compared to the two other groups. There were significant correlations among the new PR tasks, receptive vocabulary, and expressive vocabulary. Conclusion: The study results indicate that vocal rehearsals contribute to the improvement of new PR storage and retrieval in both SLI and TD children.
\end{abstract}

Keywords: Vocal rehearsal, Phonological short-term memory, New phonological representation retrieval, Specific language impairment
직접적인 가르침 없이도 아동은 새로운 단어들을 매우 빠른 속 도로 습득해간다. 이에 대해 Carey (1982)는 초기언어발달에서 가 장 주목할 만한 현상 중 하나가 학령전기 아동의 놀라운 어휘확장 속도라고 언급한 바 있다. 새로운 단어에 최소한의 노출만으로도 아동은 단어를 습득하고 저장하는 능력이 있다는 것이 여러 연구 들에서 보고되었으며, 이에 대해 일견단어학습, 빠른 매핑(fast mapping), 빠른 의미연결 등의 용어로 설명되고 있다. 즉, 그때까지는 아 동에게 무의미하였던 소리형태와 대상물의 의미가 자연스러운 환 경 속에서 한두 차례만 반복 제시되어도 아동은 소리형태와 그것 에 해당하는 의미를 빠르게 연결시킬 수 있다는 것이다. 국내에서 도 여러 유형의 의사소통장애 아동들을 대상으로 일견단어학습 에 대한 연구들이 비교적 활발하게 진행되어 왔고, 그 가운데 단순
언어장애 아동에 대한 연구들도 상당 수를 차지한다.

단순언어장애 아동은 일반적으로 어휘발달에 어려움을 보인다. 이러한 단순언어장애 아동의 어휘발달 문제를 앞에서 언급하였던 의미연결능력의 손상 이외에, 대상물에 대한 어휘적 라벨(lexical label), 즉 해당 단어를 구성하는 일련의 음운정보를 저장하는 능력 과 관련하여 설명한 연구들 또한 찾아볼수 있다(Alt \& Plante, 2006). 많은 연구에서 단순언어장애 아동은 음운적 정보를 저장하는 능 력에 어려움이 있다고 보고되었으며, 이를 음운단기기억 또는 음운 작업기억 결함으로 설명하고 있다(Alt \& Plante, 2006; Baddeley, 2003; Brackenbury \& Pye, 2005; Gathercole, Hitch, \& Martin, 1997). 음운단기기억을 측정할 수 있는 과제에는 숫자따라하기, 단어따라 말하기, 문장따라말하기, 비단어따라말하기 등이 있는데, 이 중 비 
단어따라말하기가 대상자들의 음운단기기억력을 가장 민감하게 평가할 수 있고 언어와의 상관성도 높은 것으로 보고되었다(Baddeley, Gathercole, \& Papagno, 1998). 의사소통장애를 변별할 수 있 는 민감하고 간편한 방법으로 비단어따라말하기 과제의 중요성이 부각됨에 따라, 임상 및 연구상의 목적을 위해 의사소통장애 아동 들을 대상으로 비단어따라말하기 수행력이 평가되고 있다. 단순언 어장애 아동의 경우 2 음절 이하의 짧은 비단어 자극어에 대해서는 일반 아동과 수행력 차이가 관찰되지 않지만, 3, 4음절로 길어지면 단순언어장애 아동의 수행력이 유의하게 떨어지는 것으로 보고되 었다(Munson, Kurtz, \& Windsor, 2005).

이상과 같은 연구결과들을 정리하면, 단순언어장애 아동은 제 시된 음운정보에 대해 의미를 연결시켜 대상물의 의미를 저장시키 는 능력과 새롭게 접한 일련의 음운연속체를 저장시켜 인출하는 능 력 모두에 결함을 보이며, 이것은 이들의 어휘습득 또는 단어학습 의 어려움과 깊은 연관성을 가진다. 전자는 일견단어학습 패러다임 을 이용한 실험과제를 통해, 후자는 비단어따라말하기 과제를 이 용하여 연구되어 왔다. 전자는 새로운 음운정보를 특정 의미와 연 결시킨 후 대상자에게 그 음운정보를 다시 제시하여 그것에 해당 하는 의미를 찾을 것을 요구하는 방식이다. 후자는 새롭게 접한 일 련의 소리연속체를 제시한 후 그것을 바로 따라말하게 하거나 일정 시간 후 따라말하게 하는 방법이다. 둘 다 새로운 음운정보를 제공 한다는 공통점을 가지지만, 전자는 의미저장능력에, 후자는 소리 자체의 저장과 인출능력에 초점을 두고 있다. 다시 말해 일견단어 학습은 의미처리능력에, 비단어따라말하기는 음운처리능력에 중 점을 둔다고 할 수 있다. 단어는 의미와 음운의 두 가지 측면으로 이 루어져 있다는 기본 전제를 상기할 때, 단순언어장애 아동의 어휘 습득의 결함이 이 두 가지 측면과 관련되어 있다는 것은 어떻게 보 면 당연한 것으로 여겨진다.

어휘습득 또는 단어학습과 관련하여 본 연구는 의미처리가 아 닌 음운처리에 초점을 두고 있다. 비단어따라말하기 과제를 이용 하여 새로운음운정보의 즉각적 저장과 인출능력을 살펴보았던 선 행연구들과 달리, 본 연구에서는 새 단어학습 시 새롭게 접한 대상 물에 대해 새로운 음운정보를 연결시켜 저장한 후 일정시간이 경 과하고 나서 그것을 인출하는 능력을 살펴보고자 하였다. 이때 새 로운 음운정보는 대상물과 연결되어 일시적일지라도 대상자의 단 기기억 속에 음운표상으로 형성되어야 하고, 그것을 일정시간 동안 유지시킨 후 대상물과 연결하여 정확하게 인출하는 능력이 요구된 다. 이와 유사한 연구가 말소리장애 아동 집단과 일반 아동 집단을 대상으로 실시된 바 있는데(Bae, Ha, Koo, Hwang, \& Pyun, 2016), 두 집단 모두 새로운 음운표상인출 과제에 현저한 어려움을 보인
것으로 보고되었다. 이와 관련하여 음운표상인출 과제를 성공적으 로 수행하기 위해서는 음운정보의 수동적 보유가 아닌 시연활동 (rehearsal)을 통한 적극적 보유능력이 요구된다는 점을 강조하였 다(Bae et al., 2016).

Baddeley (1986)는 그의 작업기억 모델에서 음운루프를 시연과 관련이 깊은 하위요소로 설명하고 있다. 음운루프의 시연과정과 음운저장소는 어휘습득 시 적극 활용되는 요소로, 어휘습득과정 에 필수적인 것으로 설명된다(Baddeley et al., 1998). 음운저장소의 수용능력은 극히 제한적이기 때문에 기억흔적은 2-3초가 경과하 면 소멸되고, 이를 막기 위해서는 시연전략을 능동적으로 활용해 야 한다. 시연활동, 즉 정보의 되뇌기를 통해 입력된 음운정보는 몇 분에서 몇 시간까지도 유지될 수 있다(Brookshire, 2007). Baddeley (1986)는 성인의 시연활동을 내현적 시연(subvocal rehearsal)으로 한정하여 설명하였지만, 언어발달 또는 언어교육 관련 분야에서 시 연은 외현적(vocal rehearsal)과 내현적 시연으로 구분된다. 외현적 시연은 소리 내어 되뇌는 활동으로, 내현적 시연으로 소리 내지 않 고 속으로 되뇌는 활동으로 정의되는데, 어린 아동일수록 외현적 시연이 도움이 된다(Lee, Ha, Koo, Hwang, \& Pyun, 2016). 초기에 는 외현적 시연을 통해 시연능력을 발달시켜 가다가 점차적으로 시 연활동에 익숙해지면 점차 소리 내지 않고 시연을 하는 내현적 시 연을 사용하게 된다(Lee et al., 2016).

본 연구에서는 단순언어장애 아동과 일반 아동을 대상으로 새 로운 음운표상인출 능력을 살펴보고자 하였다. 자극을 듣자마자 즉각적으로 음운표상을 인출하는 것이 아닌, 일정시간 동안 그것 을 저장, 보유, 인출하는 능력을 모두 살펴보는 것이 본 연구의 목적 이라고 할 수 있다. 선행연구(Alt \& Spaulding, 2011)에 근거하여 지 연시간을 10 초로 정하고, 이보다 더욱 부담이 되는 상황을 만들기 위해 5 분의 지연시간을 추가로 선정하였다. 음운표상을 일정시간 동안 유지하여 정해진 시간 경과 후 그것을 인출하여야 하기 때문 에 과제를 성공적으로 수행하기 위해서는 시연전략이 요구된다. 따 라서 시연전략의 사용여부에 따른 수행력 비교를 위해, 새로운 음 운표상인출 과제를 시연을 한 경우와 그렇지 않은 경우로 구분하 여 실시하였다. 시연전략을 이용하여 음운정보를 유지하는 것에 어 려움이 있는 것으로 보고된 단순언어장애 아동의 경우(Alt \& Spaulding, 2011) 내현적 시연보다 외현적 시연의 사용을 독려하는 것이 타당할 것으로 판단되어, 본 연구의 시연은 외현적 시연활동으로 한정하였다.

본 연구의 목적은 단순언어장애 아동 10 명, 단순언어장애 아동 과 언어연령을 일치시킨 일반 아동 10 명, 생활연령을 일치시킨 일반 아동 10 명을 대상으로, 외현적 시연이 일정시간 경과 후 음운표상 
인출 수행력에 어떠한 영향을 미치는지 알아보고자 하는 것이다. 이를 위해 세 집단 간 시연여부 및 지연시간 정도(10초, 5 분)에 따른 음운표상인출의 수행력을 비교 분석하고, 대상자들의 수용 및 표 현어휘력과 각 과제의 수행력 간 관련성을 살펴보았다. 이와 같은 본 연구의 연구질문들을 정리해보면 다음과 같다. 첫째, 세 집단 간 외현적 시연 여부 및 지연시간 정도에 따른 새로운 음운표상인출 수행력에 차이가 있는가? 둘째, 세 집단 간 새로운 음운표상인출 과 제 시 나타난 오류유형별 비율에 차이가 있는가? 셋째, 시연여부 및 지연시간별 새로운 음운표상인출 수행력과 대상자의 수용어휘량, 표현어휘량 간 상관관계는 어떠한가?

\section{연구 방법}

\section{연구 대상}

본 연구의 대상자는 6 세 단순언어장애 아동 10 명, 그리고 단순언 어장애 아동과 생활연령 또는 언어연령을 일치시킨 일반 아동 각각 10 명씩, 총 30 명이었다. 단순언어장애 아동은 전문 언어치료기관에 서 1 급 또는 2 급 자격증을 소지한 언어재활사에 의해 단순언어장 애로 진단받은 아동들에 대하여 다음과 같은 Leonard (2014)의 기 준을 적용하여 선별하였다. 첫째, 표준화된 어휘검사(Receptive \& Expressive Vocabulary Test, REVT; Kim, Hong, Kim, Jang, \& Lee, 2009) 결과 통합어휘연령이 생활연령에 비해 -1.25 표준편차 이하 에 속하는 아동, 둘째, 표준화된 지능검사(Korean-Kaufman Assessment Battery for Children, K-ABC; Moon \& Byun, 1997) 결과 비언어성 지능이 6세 수준인 아동, 셋째, 표준화된 조음음운검사 (Urimal Test of Articulation and Phonology, U-TAP; Kim \& Shin, 1994) 결과 말소리 발달이 정상 범위에 속하는 아동, 넷째, 청력, 구 강구조/기능, 사회적 상호작용 능력에 문제가 없고 기타 신경학적 질환을 동반하지 않은 것으로 부모 또는 담당 언어재활사가 보고 한 아동을 대상으로 하였다.

생활연령일치 집단의 선정기준은 첫째, 부모나 교사의 보고에 의 해 인지, 신체, 언어발달이 정상이며 청각 및 기타 신경학적 문제가 없는 것으로 확인된 아동, 둘째, 표준화된 어휘검사(REVT; Kim et al., 2009) 결과 통합어휘연령이 자신의 생활연령 범위 이상에 속하 는 아동, 셋째, 표준화된 지능검사(K-ABC; Moon \& Byun, 1997) 결과 비언어성 지능이 자신의 생활연령대에 속하는 아동, 넷째, 표 준화된 조음검사(U-TAP; Kim \& Shin, 1994) 결과 말소리 발달이 정상 범위에 속하는 아동, 다섯째, 이상의 조건을 충족하는 아동 가운데 단순언어장애 집단과 일대일로 대응시켰을 때 생활연령의 차이가 \pm 3 개월 이내에 속하는 아동을 대상으로 하였다. 언어연령
Table 1. Participants' characteristics

\begin{tabular}{lccc}
\hline Characteristic & SLI group & CA group & LA group \\
\hline Sex (male:female) & $7: 3$ & $3: 7$ & $6: 4$ \\
Age $(\mathrm{mo})$ & $76.80(3.32)$ & $76.72(3.06)$ & $66.80(3.55)$ \\
Receptive vocabulary age $(\mathrm{mo})^{\mathrm{a}}$ & $63.59(6.36)$ & $89.54(13.34)$ & $69.50(8.64)$ \\
${\text { Expressive vocabulary age }(\mathrm{mo})^{\mathrm{a}}}^{\mathrm{a}}$ & $61.50(4.50)$ & $83.36(13.00)$ & $67.10(7.80)$ \\
\hline
\end{tabular}

Values are presented as mean (SD).

$S L I=$ specific language impairment; $C A=$ chronical age-matched typically developing; $L A=$ language age-matched typically developing.

aReceptive \& Expressive Vocabulary Test (Kim, Hong, Kim, Jang, \& Lee, 2009).

일치 집단의 선정기준은 첫째, 부모나 교사의 보고에 의해 인지, 신 체, 언어발달이 정상이며 청각 및 기타 신경학적 문제가 없다고 확 인된 아동, 둘째, 표준화된 어휘검사(REVT; Kim et al., 2009)를 실 시하여 단순언어장애 집단과 일대일로 대응시켰을 때 통합어휘연 령의 차이가 \pm 5 개월 이내에 속하는 아동, 셋째, 표준화된 지능검 사(K-ABC; Moon \& Byun, 1997) 결과 비언어성 지능이 자신의 생 활연령대에 속하는 아동, 넷째, 표준화된 조음검사(U-TAP; Kim \& Shin, 1994) 결과 말소리 발달이 정상 범위에 속하는 아동을 대상 으로 하였다.

세 집단의 성별, 생활연령, 어휘언령에 대한 정보는 Table 1 과 같 다. 단순언어장애 집단과 생활연령 일치 일반 집단 간 생활연령에 는 유의한 차이가 없었고( $p>.05)$, 수용어휘연령과 표현어휘연령은 단순언어장애 집단이 생활연령 일치 일반 집단보다 유의하게 낮았 다 $(p<.001)$. 단순언어장애 집단과 언어연령 일치 일반 집단 간 수 용어휘연령과 표현어휘연령에는 유의한 차이가 없었고 $(p>.05)$, 생 활연령은 단순언어장애 집단이 언어연령 일치 일반 집단보다 유의 하게 높았다 $(p<.001)$. 따라서 단순언어장애 집단과 생활연령 일치 일반 집단 간에는 생활연령이, 그리고 단순언어장애 집단과 언어연 령 일치 일반 집단 간에는 어휘연령이 통제된 것으로 간주하였다.

\section{실험 과제 및 실험 방법}

비단어 자극어 선정 및 그림제작

본 연구의 목적은 새로운 단어학습 시 처음 접한 음운정보를 음 운표상으로 저장한 후 그것을 인출하는 능력을 살펴보고자 하는 것이다. 이때 대상자의 수행력은 입력된 음운정보를 처리하는 능 력, 즉 상향적 처리의 영향을 받지만, 또한 대상자의 어휘저장소에 저장되어 있는 어휘의 하향적 처리로부터도 영향을 받는다(Kim \& $\mathrm{Ha}, 2014$; Lee et al., 2016). 다시 말해 새로운 소리조합을 듣게 되면 자동적으로 어휘저장소에서 그것과 소리형태가 유사한 단어를 찾 게 되고, 그 단어의 음운형태를 떠올리며 새 단어의 소리정보를 좀 더 오랫동안 유지하는 데에 도움을 받는다는 것이다. 때문에 어휘 
저장소에 저장되어 있는 어휘의 양이 많을수록 새롭게 접한 소리형 태와 유사한 단어 또한 많이 떠올릴 수 있을 것이고, 결과적으로 새 로운 음운정보를 저장하고 인출하는 능력이 보다 우수할 가능성 을 배제할 수 없다. 본 연구의 목적이 시연에 의한 음운정보의 유지 능력, 즉음운단기/작업 능력을 살펴보는 것인 만큼 대상자들의 어 휘 양을 동일하게 통제하는 것이 이상적일 것이나 이것은 현실적으 로 불가능하다. 따라서 최대한 우리말 단어와 유사하지 않은, 단어 유사성이 매우 낮은 소리조합으로 제작된 비단어 자극어, 즉 어떤 대상자의 어휘저장소에도 해당 비단어와 음운적으로 유사한 단어 가 저장되어 있을 가능성이 높지 않은 자극어를 사용하고자 하였 다. 이에 따라 단어유사성이 낮은 비단어만으로 실험자극어가 구 성된 선행연구(Bae et al., 2016; Lee et al., 2016)에서 비단어 자극어 일부를 선택하고, Lee 등(2015)의 연구와 동일한 과정으로 비단어 자극어를 추가 제작하였다.

비단어 자극어 제작 과정은 다음과 같다. 우선 두 종류의 말뭉치 자료(Jo, 2002; Kim \& Kang, 1997)를 참고하였다. Kim과 Kang (1997) 의 “한글 사용빈도 분석”을 이용하여 단음절을 모두 추출하였다. 그러고 나서 Jo (2002)의 단음절 명사 표제어에 근거하여, 구체적 명 사로서 의미를 가지는 단음절 단어와 한국어에서 쓰이지 않는 비 사용 음절을 제외하였다. 이와 같은 과정을 통하여 1,771 개의 음절 이 추출되었다. 추출된 음절은 홀로 단어로서 기능하지 못하나(대 명사, 수사, 의존명사로는 가능함) 한국어 단어의 일부로는 사용되

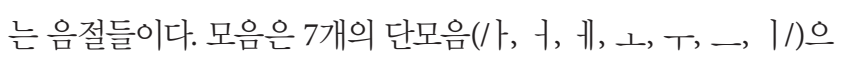
로, 종성은 7종성(/ᄀ, ᄂ, ᄃ, ㄹ, ㅁ, ㅂ, 이)으로 국한하였다. 조음 능력의 미성숙으로 인한 과제수행의 어려움을 배제하기 위하여 초 성에서 유음, 치경마찰음, 파찰음을 제외하고자 하였으나, 그럴 경 우 남는 음절이 너무 제한적이어서 유음은 포함시켰다. 이렇게 하 여 1,771 개의 예비 음절에서 최종적으로 219 개의 음절만이 남았다. 최종 219개의 단음절에 대하여 난수표를 이용한 무선 조합을 실시 하여 2, 3, 4음절 각 4 개씩, 총 12 개의 비단어 자극어(/너겝/, /두빕/, /흐넨/, /머툴/, /니버껑/, /더눌렁/, /따깅은/, /흐넬만/, /꾸머큰넥/, /두 넘몽뎅/, /니덩멜렙/, /거그쿤닌/)가 본 실험과제의 자극어로 선정되 었다(Appendix 1). 비단어 목록에 대하여 언어치료학과 학부생 130 명을 대상으로 5점 척도(1점: 단어와 매우 유사하지 않음, 5점: 단어와 매우 유사함)의 단어유사성 정도를 측정한 결과, 12 개의 자 극어 모두 평균 2.5점 이하의 점수를 획득하였다. 또한 100 만 음절 말뭉치 자료(Kim \& Kang, 1997)를 참고하여 음절빈도를 구한 결 과, 각 항목들의 평균 음절빈도는 모두 670 이상이었다. 따라서 본 연구의 비단어 자극어는 음절빈도는 높고 단어유사성은 낮은 소리 조합으로 구성되어 있다고 할 수 있다.
비단어 자극어와 연결시킬 그림제작을 위하여, 전문 일러스트레 이터에게 현실에 존재하지 않는 캐릭터 또는 사물 12 개를 창의적으 로 그려 줄 것을 의뢰하였다. 1 차 제작된 12 개의 그림에 대하여 6 세 일반 아동 10 명을 대상으로 실제로 본 사물과 비슷하게 느껴지거 나 평소에 자주 접하는 캐릭터와 비슷하다고 판단되는 그림이 있는 지 조사하였다. 아동들의 피드백을 참고하여 여러 차례 수정과정 을 거쳐 12 개의 그림이 최종 제작되었다(Appendix 1). 이중 일부 그 림은 Bae 등(2016)의 연구에서도 사용된 것이다.

\section{실험 과제 및 예비실험}

각 그림과 함께 목표 비단어(새로운 음운표상)가 동시에 제시되 는 MS 파워포인트 슬라이드를 제작하였다. 비단어 소리자극은 노 트북에 연결된 이어폰을 통하여 모든 대상자에게 2 회씩 반복 재생 되는 것을 원칙으로 하였으나, 더 들려줄 것을 요구하는 대상자에 게는 한 차례의 기회를 더 제공하였다. 직후 동일한 그림을 다시 보 여준 후 “이름이 뭐라고 했지요?”라는 질문을 통해 대상자가 그림 과 소리를 인지하였는지를 확인하였다. 이때 연구자(검사자)는 아 동의 반응에 대해 아무런 피드백을 제공하지 않았다. 그러고 나서 모든 대상자들은 10 초와 5 분 후 조금 전 보았던 그림자극의 이름 을 다시 말해줄 것을 요구 받았다. 본 실험 과제는 '비시연 과제(task without vocal rehearsal)'와 '시연 과제(task with vocal rehearsal)'로 구성되어 있어, 10 초와 5 분 동안 대상자들은 외현적 시연을 하지 않 고 가만히 있거나 외현적 시연을 실시하도록 하였다.

예비실험에서 10 초와 5 분이라는 지연시간 동안 다른 언어적 자 극을 차단하고 지루함을 방지하기 위해 그림 그리기와 퍼즐과 같은 비언어성 게임을 실시하였다. 그러나 대부분의 대상자들에서 주의 집중력 저하가 관찰되고, 이에 따라 실험 진행이 원활하게 이루어 지지 않았다. 어린 아동들은 주의를 분산시킬 경우 심성 어휘집에 서부터 음운을 선택, 계획하여 말소리를 산출하는 과정에서 음운 과 음성체계 사이에 오류를 나타낼 수 있다는 것은 이미 선행연구 에서 보고 된 바가 있다(Dodd, 1975; Singer \& Bashir, 1999; Winitz, 1975). 또한 국내 최근 연구에서 Shin (2016)은 주의 분산에 따 른 말소리장애 아동과 일반 아동의 자음정확도 차이를 알아본 결 과, 주의 분산 여부는 대상자의 과제 수행에 유의한 차이를 초래하 였다고 보고하였다. 따라서 본 연구에서는 선행연구들의 결과를 토 대로 지연시간 동안 새로운 어휘를 상기하는데 방해받지 않도록 하 기 위하여, 노트북에 나타나는 초록색 화면만 응시하도록 하였다.

\section{실험 절차}

검사는 소음이 없는 분리된 공간에서 아동과 연구자가 일대일로 
진행하였다. 실험순서는 비시연 음운표상인출 과제(연습 항목 1 개, 본 항목 6개), 시연 음운표상인출 과제(연습 항목 1개, 본 항목 6개) 순으로 진행되었다. 시연 과제를 먼저 시작할 경우 이후 비시연 과 제에서도 시연활동의 학습효과가 나타날 가능성을 배제하기 위해 비시연 과제를 먼저 진행하였다.

외현적 시연을 동반하지 않은 비시연 과제를 실시하기 위해 연구 자는 아동에게 "선생님이 노트북으로 이 세상에 존재하지 않은 괴 물 친구들이랑, 그 친구들의 이름을 들려줄 거예요. 괴물 친구들 이 름을 잘 듣고 기억했다가 10 초 후 그리고 5 분 후 선생님한테 다시 말해주세요.”라고 설명하였다. 연습항목을 포함한 총 7개의 그림 과 비단어 자극어를 짝지어 아동은 새로운 단어를 2 회씩 들을 수 있었고, 한 항목을 보여주고 나서 10 초와 5 분 후 “이 친구 이름이 뭐 였지요?”라고 각각 질문하였다. 외현적 시연을 동반한 시연 과제를 실시하기 위해 연구자는 "선생님이 괴물 친구들 그림이랑 그 친구 들 이름을 들려줄 거예요. 그러고 나서 10 초와 5 분 후에 그 친구들 이름을 다시 물어 볼 건데, 그 동안 입으로 /느닙, 느닙, 느닙, 느닙, 느 닙/ 이렇게 여러 번 소리를 내서 연습하면 친구들 이름을 더 잘 기억 할 수 있을 거예요."라고 설명하였다. 이상과 같은 새로운 음운표상 인출 과제 절차의 구성 예는 Figure 1과 같다. 모든 실험 과정은 녹 음기에 녹음되었다.

\section{자료 처리 및 통계 분석}

과제 정확도는 선행연구에 근거하여(Kim \& Ha, 2014) 정확한 위 치에서 정확하게 인출한 자음과 모음에 각 1 점씩 부여한 후, 전체 음소에 대한 인출 음소의 백분율로 구하였다. 즉, 산출해야 할 총 음소 수를 분모로, 정확한 위치에서 정확하게 인출한 음소 수를 분 자로 하여 백분율을 구하였다. 오류유형 분석 위해 전체 대상자들 의 오류를 모두 기술한 후 동일한 오류를 그룹으로 묶어 전체 오류 유형을 범주화 하였다. 그 결과 대상자들이 보인 오류유형은 음절 생략, 음소생략, 음소대치, 음소첨가, 어휘화, 무반응의 6가지로 분 류할 수 있었다. 이중 어휘화 오류는 비단어 자극어를 우리말에 존 재하는 단어로 바꾸어 말하는 경우를 의미한다. 시연 여부 및 지연 시간 정도에 따라 하위과제별로 각각 분석했을 경우 과제별 오류 유형의 수가 너무 적은 수로 분포되어, 오류유형 분석은 하위과제 별로 구분하지 않고 전체 과제에 대해 구하였다. 마지막으로 새로 운 음운표상인출 수행력과 대상자의 수용어휘력, 표현어휘력과의 상관관계는 집단을 구분하지 않은 채 전체 대상자를 대상으로 비 시연 과제 수행력, 시연 과제 수행력, REVT의 수용어휘 원점수 및 표현어위 원점수에 대한 상관관계를 살펴보았다.

SPSS (statistics package for the social science, version 20.0 for Window)를 이용하여 다음과 같은 방법으로 자료의 통계분석을

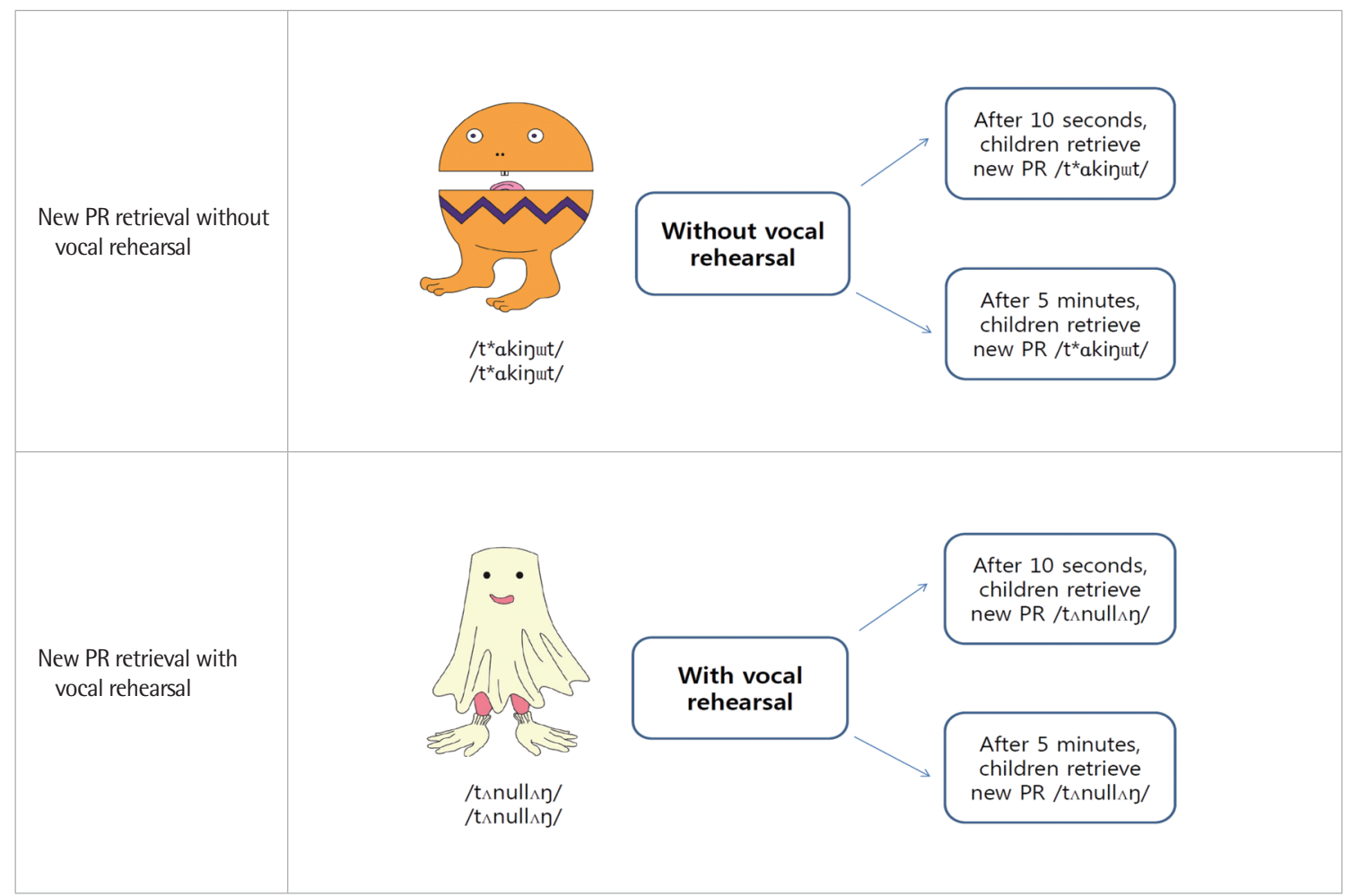

Figure 1. Procedures of new phonological representation (PR) task with and without vocal rehearsals. 
실시하였다. 첫째, 세 집단 간 외현적 시연 여부 및 지연시간 정도에 따른 새로운 음운표상인출 수행력 차이를 알아보기 위해 1피험자 간-2피험자 내 혼합설계에 따른 반복측정 분산분석을 실시하였다. 둘째, 세 집단 간 음운표상인출 과제 시 나타난 오류유형별 비율을 알아보기 위해 1피험자 간-1피험자 내 혼합설계에 따른 반복측정 분산분석을 실시하였다. 셋째, 새로운 음운표상인출 수행력과 대 상자의 수용어휘력, 표현어휘력과의 상관관계를 알아보기 위해, 각 과제 수행력 간 Pearson 상관분석을 실시하였다.

\section{신뢰도}

음운표상인출 수행력에 대한 신뢰도를 검증하기 위해 평가자 간 신뢰도를 산출하였다. 제 1 평가자는 본 연구자였고, 제 2 평가자는 사 설 기관에서 근무하는 임상 경력 8 년 이상의 2 급 언어재활사 자격 증 소지자였다. 제 1 평가자는 제 2 평가자에게 분석에 대한 지침을 설 명하였다. 여러 차례의 연습과 논의를 통하여 대상자 2 명에 대한 두 평가자 간 일치도가 $98 \%$ 이상인 것을 확인한 후, 신뢰도 평가를 실 시하였다. 전체 대상자의 $20 \%$ 에 해당하는 6 명의 자료를 무작위로 추출하였다. 신뢰도는 일치한 항목수와 불일치한 항목수의 합을 일치한 항목수로 나눈 후 100 을 곱하여 산출하였다. 비시연 과제의 10 초와 5 분 후 수행력에 대한 일치도는 $92.8 \%, 90 \%$, 시연 과제의 10 초와 5 분 후 수행력에 대한 일치도는 $87 \%, 94.7 \%$ 이었다.

\section{연구 결과}

\section{세 집단 간 외현적 시연 여부 및 지연시간 정도에 따른 새로운 음운표상인출 수행력 비교}

세 집단 간 시연 여부 및 10 초와 5 분이라는 지연시간 정도에 따른 새로운 음운표상인출수행력을 살펴본 결과, 비시연 과제에서 10 초 와 5 분 후 평균점수는 단순언어장애 집단 59.65 (23.18)점, 28.25 (15.48)점, 언어연령일치 일반 집단 72.60 (22.05)점, 41.95 (23.28)점, 생활연령일치 일반 집단 89.52 (4.94)점, 68.96 (20.37)점이었다. 시연 과제에서 10 초와 5 초 후 평균점수는 단순언어장애 집단 62.07 (17.59) 점, 44.92 (26.17)점, 언어연령일치 일반 집단 76.73 (18.16)점, 52.60 (21.59)점, 생활연령일치 일반 집단 94.66 (5.35)점, 79.24 (17.26)점이 었다(Figure 2).

이러한 차이가 통계적으로 유의한지 알아보기 위하여 1피험자 간-2피험자 내 혼합설계에 따른 반복측정 분산분석을 실시한 결 과, 집단 간 주효과 $\left(F_{(2,27)}=14.08, p<.001\right)$ 와 시연 여부에 따른 집단 내 주효과 $\left(F_{(1,27)}=6.029, p<.05\right)$ 가 유의하였다. 그러나 집단과 시연 여부의 상호작용효과는 유의하지 않았다 $\left(F_{(2,27)}=.038, p>.05\right)$. 집

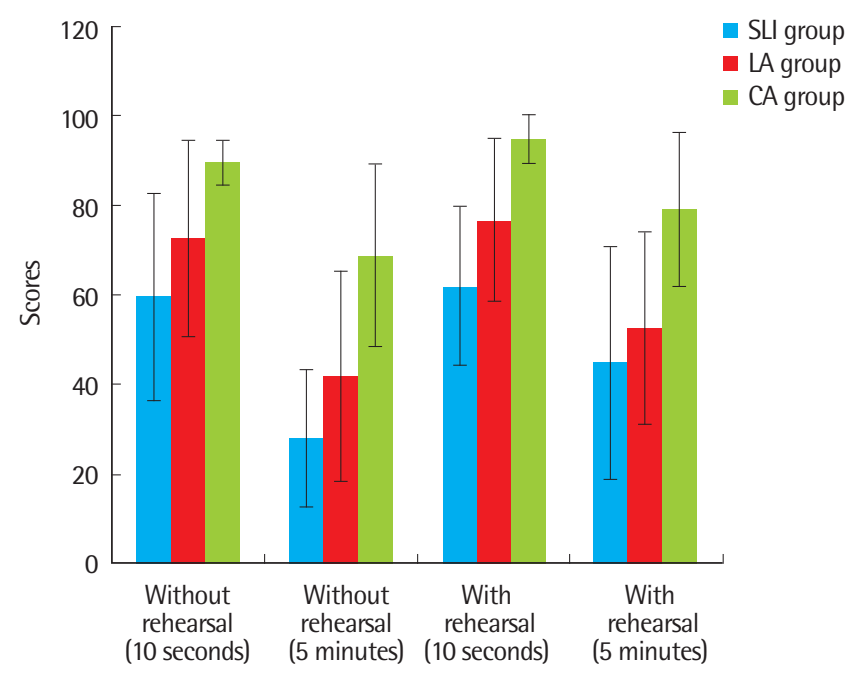

Figure 2. Scores of the new phonological representation tasks with and without vocal rehearsals. $S L I=$ specific language impairment; $C A=$ chronical agematched typically developing; $L A=$ language age-matched typically developing.

단 간 주효과에 대한 Scheffé 사후검정 결과, 단순언어장애 집단과 생활연령일치 일반 집단 간 $(p<.001)$ 및 생활연령일치 일반 집단과 언어연령일치 일반 집단 간 $(p<.01)$ 유의한 차이를 확인할 수 있었 다. 또한 10 초와 5 분이라는 지연시간에 따른 집단 내 주효과 $\left(F_{(1,27)}=\right.$ $108.02, p<.001)$ 와 시연 여부와 지연시간의 상호작용효과 $\left(F_{(1,27)}=\right.$ $8.901, p<.01)$ 가 유의하였으나, 집단과 시간의 상호작용효과는 유 의하지 않았다 $\left(F_{(2,27)}=1.629, p>.05\right)$. 시연 여부와 지연시간의 상호 작용효과를 구체적으로 분석하기 위해, COMPARE 하위명령어를 입력한 syntax를 실행시켜 사후검정을 실시하였다. 그 결과 10 초 지 연시간 후에는 시연 여부에 따른 유의한 차이가 없었던 반면( $p>.05)$, 5 분 지연시간 후에는 비시연 과제보다 시연 과제의 점수가 유의하 게 높은 것을 확인할수 있었다 $(p<.01)$.

\section{세 집단 간 새로운 음운표상인출 과제수행 시 나타난 오류유형 비율 비교}

단순언어장애 집단의 경우 음소대치 $45.12 \%$ (11.36), 음절생략 $21.60 \%$ (12.32), 무반응 $14.37 \%$ (8.22), 음소생략 $12.77 \%$ (6.91), 어휘 화 $3.46 \%$ (4.53), 음소첨가 $2.50 \%$ (3.42) 순으로 오류를 나타내었다. 언어연령일치 집단은 음소대치 $51.70 \%$ (11.91), 음소생략 $24.55 \%$ (9.33), 음절생략 9.08\% (4.07), 무반응 8.17\% (15.08), 음소첨가 6.46\% (7.00) 순으로, 생활연령일치 집단은 음소대치 $55.24 \%$ (13.98), 음소 생략 $31.99 \%$ (12.73), 음소첨가 $4.29 \%$ (4.77), 음절생략 $3.06 \%$ (7.40), 무반응 $1.58 \%$ (2.76) 순으로 오류를 나타내었다. 어휘화 오류는 단 순언어장애 집단에서만 관찰되었다(Figure 3). 


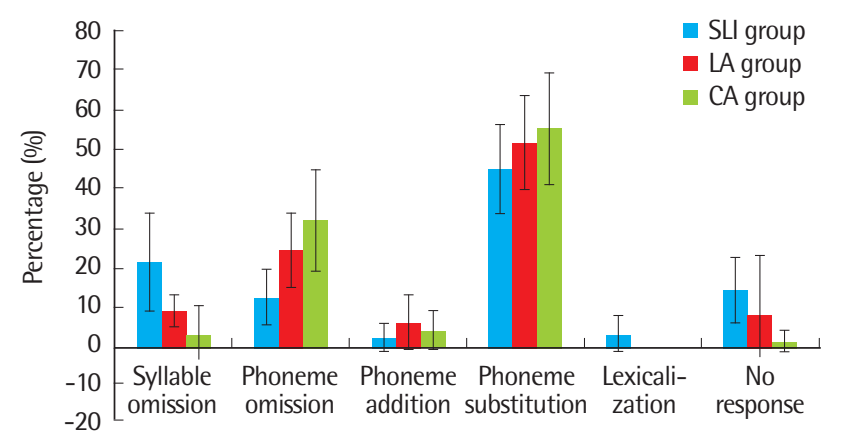

Figure 3. The percentage of error types. SLI=specific language impairment; $C A=$ chronical age-matched typically developing; $L A=$ language age-matched typically developing.

이러한 차이가 통계적으로 유의한지 알아보기 위해 1피험자 간-1 피험자 내 혼합설계에 따른 반복측정 분산분석을 실시하였다. 집 단 간 주효과는 유의하지 않았으나 $\left(F_{(2,27)}=.677, p>.05\right)$, 이는 전체 오류에 대해 각 오류유형별 백분율로 분석하였기 때문에 나타난 당연한 결과이다. 집단 내 주효과가 유의하였고 $\left(F_{(3.161)}=112.024\right.$, $p<.001)$. 집단과 오류유형 간 상호작용효과 또한 유의한 것으로 나 타났다 $\left(F_{(6,323)}=5.689, p<.001\right)$. 오류유형에 대한 주효과가 유의하 였으므로 각 오류유형 간 구체적인 차이를 알아보기 위해, Bonferroni 사후검정을 실시하였다. 이때 다중비교로 인한 1 종 오류의 증 가를 조절하기 위해 Bonferroni alpha correction을 적용하여 유의 도 수준을 .005로 낮추어 결과를 해석하였다. 그 결과 집단에 상관 없이 음소대치는 나머지 오류들보다, 음소생략은 음소첨가, 어휘화, 무반응보다, 음절생략은 어휘화보다 유의하게 많이 발생하였다 $(p<.005)$. 그리고 집단과 오류유형 간 상호작용효과를 구체적으로 분석하기 위해 COMPARE 하위명령어를 입력한 syntax를 실행시 켜 사후검정을 실시하였다. 그 결과 언어연령일치 일반 집단과 생활 연령일치 일반 집단의 경우 단순언어장애 집단보다 음소생략, 음소 대치의 오류를 유의하게 많이 보였고 $(p<.05)$, 단순언어장애 집단 은 나머지 두 집단보다 음절생략, 어휘화, 무반응을 유의하게 많이 보였다 $(p<.05)$. 반면 음소첨가와 음소대치에서는 세 집단 간 유의 한차이가 나타나지 않았다( $p>.05)$.

\section{새로운 음운표상인출 수행력과 수용어휘력, 표현어휘력 간 상관관계}

새로운 음운표상인출 수행력과 수용어휘력, 표현어휘력의 상관 관계를 분석한 결과, 수용어휘력(REVT 수용어휘 원점수)은 비시 연 10 초, 비시연 5 분, 시연 10 초, 시연 5 분 후 과제 수행력과 상관관 계수가 각각 $.543, .588, .594, .517$ 로 유의한 정적 상관관계를 보였다 ( $p<.01)$. 표현어휘력(REVT 표현어휘 원점수)은 비시연 10초, 비시
연 5 분, 시연 10 초, 시연 5 분 후 과제 수행력과 상관관계수가 각각 $.608, .698, .657, .664$ 로 유의한 정적 상관관계를 보였다 $(p<.01)$.

\section{논의 및 결론}

본 연구에서는 단순언어장애 집단, 언어연령 일치 일반 집단, 생 활연령 일치 일반 집단 간 외현적 시연 여부에 다른 새로운 음운표 상인출 수행력을 10 초와 5 분이라는 지연시간별로 비교하고, 과제 수행 시 나타난 오류유형에 대해 집단 간 비교 분석을 실시하였다. 그리고 지연시간별 비시연 과제와 시연 과제의 음운표상인출 수행 력과 대상자들의 수용어휘력, 표현어휘력 집단 간 상관관계를 살펴 보았다. 그 결과 음운표상인출 수행력은 세 집단 간 유의한 차이가 있었고, 세 집단 모두에서 시연 비동반 과제보다 동반 과제에서 수 행력이 유의하게 좋았다. 집단에 상관없이 10 초 후의 수행력은 5 분 후보다 유의하게 좋았고, 시연 여부와 지연시간 정도의 상호작용효 과 분석을 통해 10 초 후에는 시연 비동반 과제와 동반 과제의 수행 력에 차이 없었던 반면, 5 분 후에는 시연 동반 과제의 수행력이 유 의하게 좋다는 것을 알 수 있었다. 음운표상인출 과제 시 나타난 오 류유형 분석 결과, 일반아동의 두 집단은 단순언어장애 아동 집단 보다 음소생략, 음소대치와 같은 음소 수준의 오류를 유의하게 많 이 보인 반면, 단순언어장애 아동 집단은 일반 아동 집단들보다 음 절생략, 어휘화, 무반응을 유의하게 많이 보였다. 그리고 모든 과제 의 수행력은 대상자들의 수용어휘력 및 표현어휘력과 유의한 정적 상관관계가 있다는 것 또한 확인할 수 있었다.

우선 새로운 음운표상인출 수행력의 집단 간 차이에 대한 사후 분석 결과, 단순언어장애 집단은 생활연령일치 일반 집단 간 유의 한 차이를 보였으나 언어연령일치 일반 집단 간에는 유의한 차이를 보이지 않았다. 이러한 결과는 단순언어장애 아동이 일반 아동보 다 비단어따라말하기와 같은 음운단기 기억력이 떨어진다는 연구 (Coady \& Evans, 2008; Dollaghan \& Campbell, 1998; Ellis Weismer et al., 2000; Munson et al., 2005), 특히 음운표상을 새롭게 형 성하는 데에 어려움이 있다는 연구(Edwards \& Lahey, 1998), 이러 한 어려움은 결국 어휘습득의 결함으로 연결된다는 연구(Gathercole \& Baddeley, 1989)들과 맥락을 같이 한다. 단순언어장애 아동 이 새로운 단어에 노출될 경우 대상물의 의미를 새롭게 접한 음운 정보와 빠르게 연결하는 일견단어학습에 어려움이 있다는 것은, 서론에서도 언급하였듯이, 여러 선행연구들을 통해 알려져 있다 (Alt \& Plante, 2006). 이뿐 아니라 이들은 대상물의 음운정보를 단 기기억에 보유하고 그것을 인출하는 능력, 즉 새로운 음운표상의 형성, 인출 능력에도 결함이 있다는 것을 본 연구를 통해 알 수 있었 
다. 따라서 단순언어장애 아동에게 단어를 학습시킬 때에는 의미와 음운정보의 연결, 의미표상과음운표상의 형성 및 인출이라는 의미 처리와음운처리의 두 가지 측면 모두에 초점을 두어야 할 것이다.

외현적 시연의 활용은 세 집단 모두에서 새로운 음운표상의 형 성과 인출에 유의하게 도움이 되었다. 일반아동의 경우 시연활동 이 음운단기기억력을 향상시키고(Lee et al., 2016), 소리 내어 반복 하는 것이 마음속으로 암기하는 것보다 단어를 회상하는 데에 효 과적이라는 것(Ellis \& Beaton, 1993; Han, 2012)은 선행연구들에서 이미 보고된 바 있다. 본 연구결과는 단어학습 시 소리 내어 되뇌는 것이 일반 아동뿐 아니라 단순언어장애 아동에게도 효과적인 방법 이라는 것을 확인시켜 주었다. 뿐만 아니라 본 연구에서는 10 초와 5 분이라는 지연시간에 차이를 두어 시연여부에 따른 인출 수행력의 차이에 대해서도 알아보았다. 집단과 시연여부에 상관없이 10 초보 다 5 분의 지연시간에서 수행력이 더 떨어진 것은 단기기억 저장소 는 제한된 용량시스템이기 때문에 새로운 정보가 입력되면 그 정보 는 몇 초 내에 소멸된다는 Baddeley (1986)의 작업기억 이론에 근거 할 때 당연한 결과로 여겨진다. 더 나아가 시연여부와 지연시간 정 도에 따른 유의한 상호작용효과, 즉 시연 효과가 10 초 후에는 나타 나지 않았던 반면, 5 분 후에는 유의하였다는 결과 또한 제한된 용 량을 가지는 단기기억 저장소는 시연활동을 통해 최대 몇 분 또는 몇 시간 동안 입력정보를 유지할 수 있다는 Baddeley (1986)의 작업 기억 이론으로 설명이 가능할 것이다. 5 분으로 길어진 지연시간으 로 인해 시연활동이 필요하였고, 이를 활용하지 않은 경우 새로운 음운정보를 보유하는 데에 어려움이 있었던 것으로 보인다.

또한 오류유형 분석을 통해 과제수행 시 나타난 오류유형 분포 에 집단 간 차이가 있음을 알 수 있었다. 세 집단 모두 음소대치 오 류를 가장 빈번하게 보였으나(Figure 2), 언어연령일치 집단과 생활 연령일치 집단의 경우 단순언어장애 집단보다 음소대치, 음소생략 의 비율이 유의하게 높았던 반면, 단순언어장애 집단은 나머지 두 집단보다 음절생략, 어휘화, 무반응의 비율이 유의하게 높았다. 일 반 아동은, 생활연령이 언어연령일치 일반 아동조차도, 음소 차원 의 오류가 많은 비중을 차지하였으나 단순언어장애 아동은 이 보 다 더 큰 단위인 음절을 생략하거나 적절한 반응을 전혀 못하는 무 반응을 많이 보였다. 이 또한 단순언어장애 아동의 제한된 음운정 보 보유능력을 재차 확인시켜 주는 결과이다. 뿐만 아니라 일반 아 동의 두 집단에서 한 차례도 관찰되지 않았던 어휘화 오류가, 그 비 율이 높지는 않지만 단순언어장애 아동 집단에서 나타났다는 점 도 흥미롭다. 어휘화는 제시된 비단어 자극어와 음운적으로 유사 한 단어 혹은 제시된 비단어와 음운적으로 전혀 관련성은 없으나 의미를 가진 단어의 형태로 바꾸어 반응한 오류이다. 예를 들어 비
단어/두넘몽뎅/을 제시하였을 때 자극어와 음운적으로 유사하지 는 않으나 의미를 가진 '부침개'라는 단어로 바꾸어 말한 경우, 동 일한 자극어에 대해 10 초 후 음운적으로 유사한 ‘두부로 말하였다 가 5 분 후에는 그것을 ‘두더지’라는 단어로 바꾼 경우 등이 그 예이 다. 이러한 오류는 음운정보에 대해 의미와 빠르게 연결시키고 그 것을 유지하는 것의 어려움(Dollaghan \& Campbell, 1998) 및 일정 시간 동안 음운정보를 유지하는 능력의 결함 등 입력자극의 상향 적(bottom-up) 처리능력의 제한으로 인해, 장기기억의 어휘저장소 에 의존하여 정보를 처리하는 하향적(top-down) 접근을 보다 활발 하게 활용하였기 때문에 나타난 것으로 보인다. 이는 본 연구에서 단어유사성이 낮은 비단어만을 사용했음에도 불구하고 새로운 음 운정보를 보유하고 인출하는 것이 단순언어장애 아동에게 얼마나 부담이 큰 과제였는지를 추측하게 해준다. 더불어 비단어따라말하 기 과제의 단어유사성 효과와 관련하여, 어휘량이 많을수록 비단 어 자극어와 음운적으로 유사한 단어형태를 더 많이 떠올릴 수 있 고 이것이 과제수행에 긍정적 영향을 준다는 해석(Lee et al., 2016; Munson et al., 2005)을 의사소통장애 아동에게 그대로 적용할 수 없을 것이라는 점 또한 시사한다. 또래 아동보다 어휘량이 적은 단 순언어장애 아동의 경우에도 자극어와 유사한 단어들을 적극적으 로 활용하여 새로운 음운정보를 보유하는 데에 도움을 받으려고 노력하였다. 그러나 두 집단의 다른 점은 일반 아동의 경우 자극어 와 음운적으로 유사한 단어를 장기기억에서 찾아내었다 하더라도 그것을 억제(inhibition)하고 최종적으로는 비단어로 반응하는 반 면, 단순언어장애 아동은 그렇게 하지 못하고 단어를 그대로 산출 한다는 점이다. 이는 단순언어장애와 관련하여 주의력 할당, 집행 기능, 억제기능을 포함한 작업기억능력 등의 결함을 언급한 여러 선행연구들(Im-Bolter, Johnson, \& Pascual-Leone, 2006; Marton, Kelmenson, \& Pinkhasova, 2007)과 맥락을 같이 하는 것으로 보인 다. 그러나 시연여부와 지연시간의 정도와 상관없이 모든 과제의 수 행력이 대상자의 수용어휘량 및 표현어휘량과 유의한 정적 상관관 계가 있었다는 연구결과는 음운작업기억 능력과 어휘량의 근본적 인 연관성에 대해서는 부정할 수 없다는 점 또한 시사한다.

실험을 진행하면서 인상적이었던 점은 비시연 과제 시 시연활동 에 대해 어떠한 독려도 하지 않았음에도 불구하고 일반 아동의 경 우에는, 생활연령이 어린 언어연령일치 일반 아동조차, 새롭게 노 출된 음운정보를 좀 더 오랫동안 보유하기 위해 자발적으로 외현 적 시연을 활용하는 모습이 빈번하게 관찰되었다는 것이다. 반면 단순언어장애 집단은 외현적 시연에 대해 충분한 설명과 연습을 실 시하였던 시연 과제에서조차도 시연활동을 적극적으로 활용하지 않는 경우가 많았다. 시연을 하기는 하였으나 제대로 활용하지 못 
하는 모습도 관찰되었는데, 그 예로 /니버껑/이라는 비단어 자극어 에 대해 /니버껑/, /미버껑/, /미더떵/과 같이 시연을 할수록 오히려 자극어로부터 음운적으로 멀어지는 경우를 들 수 있다. 따라서 언 어산출에 결함이 있는 의사소통장애 아동의 경우 외현적 시연활 동이 주의력을 분할시켜 음운정보의 보유에 오히려 방해가 될 가 능성에 대해서도 생각해보아야 할 것이다. 이와 관련하여서는 추 후 보다 객관적이고 타당한 방법을 통해 심도 있는 연구를 진행해 볼 필요가 있다.

본 연구에서는 단순언어장애 아동의 새로운 어휘습득의 제한점 을 전제하고, 외현적 시연이라는 능동적 암송책략을 활용하였을 때 일반 아동과 비교하여 음운표상인출 능력에 어떠한 차이가 있 는지를 알아보고자 하였다. 음운정보와 의미를 빠르게 연결하는 일견단어학습은 배제원리전략(Golinkoff \& Hirsh-Pasek, 1999)과 문맥전략(Rice, Oetting, Marquis, Bode, \& Pae, 1994)에 의존하는 것에 반해, 의미에 대해 음운정보를 저장하고 인출하는 능력은 일 반 아동과 단순언어장애 아동 모두 시연전략으로 도움을 받을 수 있음을 본 연구를 통해 알 수 있었다. 이와같은 연구결과는 단순언 어장애 아동의 제한된 어휘력 증진을 위한 치료활동 시 외현적 시 연을 활용해볼 필요가 있음을 시사한다는 점에서 의의가 있다. 그 러나 이와 같은 연구의 의의에도 불구하고 본 연구는 방법 및 결과 해석상 몇 가지 제한점 또한 가지고 있다. 무엇보다 대상자의 수가 적었다는 제한점은 단순언어장애 집단이 이질적 특성들을 가진 다 양한 아동들로 구성된 집단이라는 점을 간과한 것이다. 또한 아동 이 자발적으로 나타내는 내현적 또는 외현적 시연에 대해 보다 구 체적인 통제가 필요하다. Lee 등(2016)의 연구에 따르면, 시연 억제 조건에서 자음변별능력과 표현어휘량이 음운단기기억 과제의 수 행력을 예측하였다. 이러한 결과는 시연활동이 억제되고 숫자라는 방해자극을 읽어야 하는 상황에서도 아동들은 과제를 성공적으 로 수행하기 위해, 장기기억 속에 저장되어 있는, 방금 전 들었던 자 극어와 유사한 형태의 어휘를 떠올리며 음운완충기(phonological buffer) 내에 비단어 자극어를 유지하려는 하향접근적(top-down approach) 노력을 하고 있음을 보여준다. 본 연구의 경우 과제를 성 공적으로 수행하기 위해 아동이 자발적으로 행하였던 내현적 시연 까지 통제하는 데에는 다소 어려움이 있었다. 뿐만 아니라 몇몇 아 동은 제시한 자극어가 아닌 엉뚱한 비단어로 시연활동을 시작하기 도 하였는데, 이 경우 아동의 과제수행 저하가 제한된 단기기억에 기인한 것인지, 아니면 말지각능력의 결함에 의한 것인지를 판단하 기는 어렵다. 이는 비단어를 사용하는 모든 실험과제의 제한점일 것이다. 즉, 자극의 입력과 반응의 구어산출을 모두 요구하는 과제 특성상 대상자의 결함이 비단어따라말하기 과제수행 시 동반되는
다양한 기저처리과정 중 어느 단계의 결함으로부터 비롯된 것인지 에 대한 명확한 파악은 불가능하다. 따라서 추후 대상자 수를 충분 히 확보한 후 대상자 특성에 따라 단순언어장애 집단을 하위집단 들로 분류하여 각 집단별 수행력을 비교하거나, 보다 세부적인 특 정 능력에만 초점을 두고 그 이외 변수들은 체계적으로 통제한 후 실험결과를 도출해내려는 노력이 요구된다.

\section{REFERENCES}

Alt, M., \& Plante, E. (2006). Factors that influence lexical and semantic fast mapping of young children with specific language impairment. Journal of Speech, Language, and Hearing Research, 49, 941-954.

Alt, M., \& Spaulding, T. (2011). The effect of time on word learning: an examination of decay of the memory trace and vocal rehearsal in children with and without specific language impairment. Journal of Communication Disorders, 44, 640-654.

Baddeley, A. (1986). Working memory. Oxford: Oxford University Press.

Baddeley, A. (2003). Working memory and language: an overview. Journal of Communication Disorders, 36, 189-208.

Baddeley, A., Gathercole, S., \& Papagno, C. (1998). The phonological loop as a language learning device. Psychological Review, 105, 158-173.

Bae, S. R., Ha, J. W., Koo, M. M., Hwang, Y. M., \& Pyun, S. B. (2016). New phonological representation of children with speech sound disorders. Communication Sciences \& Disorders, 21, 24-36.

Brackenbury, T., \& Pye, C. (2005). Semantic deficits in children with language impairments: issues for clinical assessment. Language, Speech, and Hearing Services in Schools, 36, 5-16.

Brookshire, R. H. (2007). Introduction to neurogenic communication disorders (7th ed.). St. Louis, MO: Mosby/Elsevier.

Carey, S. (1982). Semantic development: the state of the art. In E. Wanner \& L. R. Gleiman (Eds.), Language acquisition: the state of the art (pp. 347-389). New York, NY: Cambridge University Press.

Coady, J. A., \& Evans, J. L. (2008). Uses and interpretations of non-word repetition tasks in children with and without specific language impairments (SLI). International Journal of Language \& Communication Disorders, 43, $1-40$.

Dodd, B. (1975). Children's understanding of their own phonological forms. The Quarterly Journal of Experimental Psychology, 27, 165-172.

Dollaghan, C., \& Campbell, T. F. (1998). Nonword repetition and child language impairment. Journal of Speech, Language, and Hearing Research, 41, 
1136-1146.

Edwards, J., \& Lahey, M. (1998). Nonword repetitions of children with specific language impairment: exploration of some explanations for their inaccuracies. Applied Psycholinguistics, 19, 279-309.

Ellis, N. C., \& Beaton, A. (1993). Psycholinguistic determinants of foreign language vocabulary learning. Language Learning, 43, 559-617.

Ellis Weismer, S., Tomblin, J. B., Zhang, X., Buckwalter, P., Chynoweth, J. G., \& Jones, M. (2000). Nonword repetition performance in school-age children with and without language impairment. Journal of Speech, Language, and Hearing Research, 43, 865-878.

Gathercole, S. E., \& Baddeley, A. D. (1989). Evaluation of the role of phonological STM in the development of vocabulary in children: a longitudinal study. Journal of Memory and Language, 28, 200-213.

Gathercole, S. E., Hitch, G. J., \& Martin, A. J. (1997). Phonological short-term memory and new word learning in children. Developmental Psychology, 33, 966-979.

Golinkoff, R. M., \& Hirsh-Pasek, K. (1999). How babies talk: the magic and mystery of language in the first three years of life. New York, NY: Dutton.

Han, M. J. (2012). The effect of the oral repetition learning strategy and the phonological memory capacity on Korean vocabulary learning (Master's thesis). Ewha Womans University, Seoul. Korea.

Im-Bolter, N., Johnson, J., \& Pascual-Leone, J. (2006). Processing limitations in children with specific language impairment: the role of executive function. Child Development, 77, 1822-1841.

Jo, N. H. (2002). The frequency of modern Korean words. Seoul: National Institute of the Korean Language.

Kim, H. K., \& Kang, B. M. (1997). The analysis of Korean word frequency. Seoul: Korea University, Research Institute of Korea Studies.

Kim, N. Y., \& Ha, J. W. (2014). Phonological representations in children with articulation and phonological disorders. Communication Sciences \& Disorders, $19,226-237$.
Kim, Y. T., \& Shin, M. J. (2004). Urimal Test of Articulation and Phonology (U-TAP). Seoul: Hakjisa.

Kim, Y. T., Hong, G. H., Kim, K. H., Jang, H. S., \& Lee, J. Y. (2009). Receptive \& expressive vocabulary test (REVT). Seoul: Seoul Community Rehabilitation Center.

Lee, S. J., Ha, J. W., Koo, M. M., Hwang, Y. M., \& Pyun, S. B. (2016). Delayed non-word repetition according to rehearsal conditions in 6-to 7-year-old children. Communication Sciences \& Disorders, 21, 69-83.

Leonard, L. B. (2014). Children with specific language impairment. Cambridge, MA: MIT Press.

Marton, K., Kelmenson, L., \& Pinkhasova, M. (2007). Inhibition control and working memory capacity in children with SLI. Psikhologyah, 50, 110-121.

Moon, S. B., \& Byun, C. (1997). K-ABC (Korean-Kaufman Assessment Battery for Children). Seoul: Hakjisa.

Munson, B., Kurtz, B. A., \& Windsor, J. (2005). The influence of vocabulary size, phonotactic probability, and wordlikeness on nonword repetitions of children with and without specific language impairment. Journal of Speech, Language, and Hearing Research, 48, 1033-1047.

Rice, M. L., Oetting, J. B., Marquis, J., Bode, J., \& Pae, S. (1994). Frequency of input effects on word comprehension of children with specific language impairment. Journal of Speech, Language, and Hearing Research, 37, 106122.

Shin, Y. N. (2016). Comparison of percentage of consonants correct between children with speech sound disorder and typically developing children according to distraction tasks (Master's thesis). Daegu University, Gyeongsan, Korea.

Singer, B. D., \& Bashir, A. S. (1999). What are executive functions and selfregulation and what do they have to do with language-learning disorders? Language, Speech, and Hearing Services in Schools, 30, 265-273.

Winitz, H. (1975). From syllable to conversation. Baltimore, MD: University Park Press. 
Appendix 1. 새로운 음운표상인출 과제의 그림과 자극어

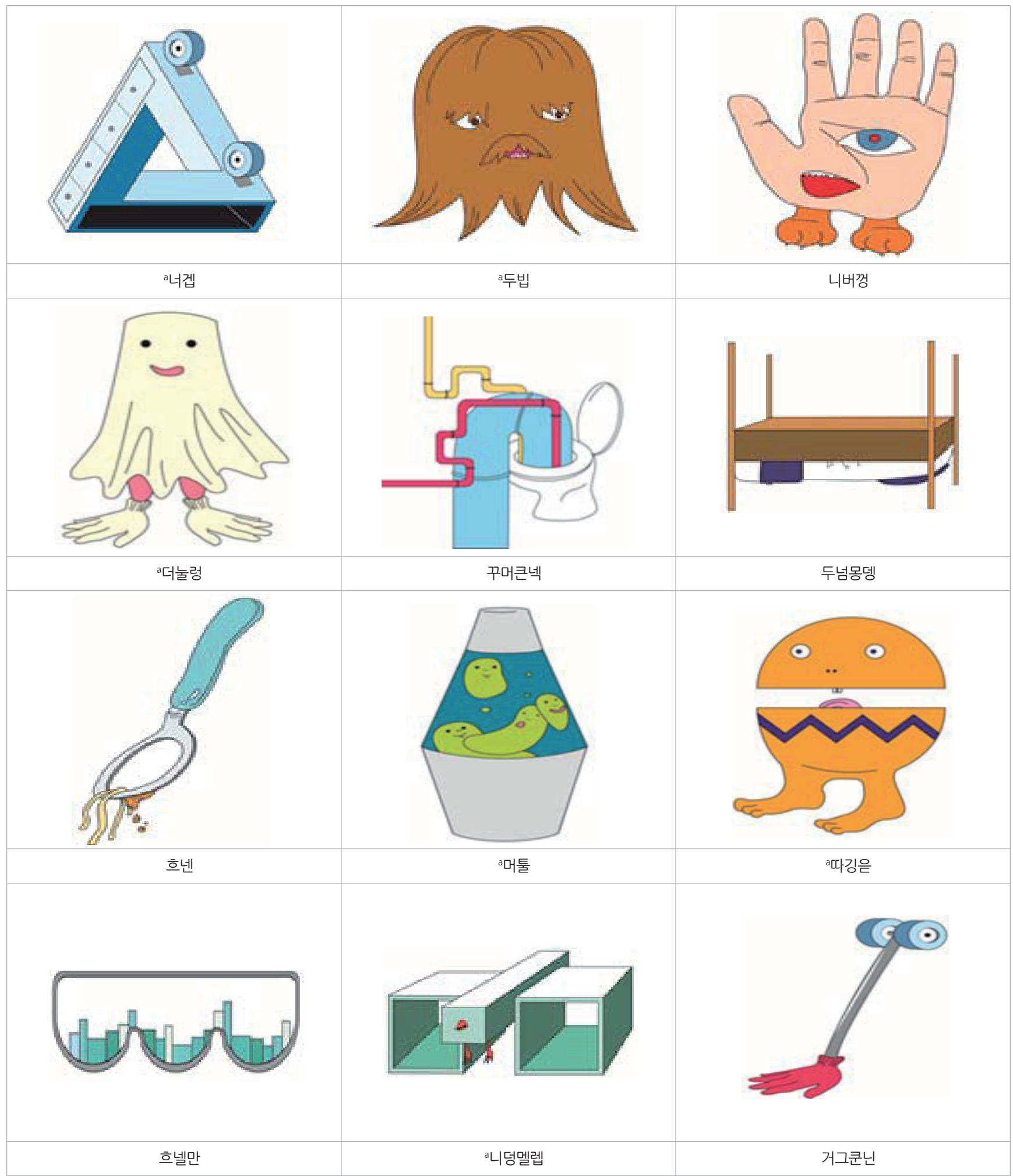

${ }^{a} \mathrm{Bae}, \mathrm{Ha}$, Koo, Hwang, \& Pyun (2016)의 연구에서 동일한 그림이 사용되었음. 


\section{국문초록}

\section{외현적 시연이 단순언어장애아동과 일반아동의 새로운 음운표상인출 수행력에 미치는 영향 류은주 $\cdot$ 하지완 ${ }^{12}$ \\ ${ }^{1}$ 대구대학교 재활과학대학원 언어치료학과, ${ }^{2}$ 대구대학교 언어치료학과}

배경 및 목적: 단순언어장애 아동 집단과 언어연령 또는 생활연령을 일치시킨 일반 아동 집단 간 외현적 시연 여부에 따라 10 초와 5 분 후 음운표상인출 수행력에 어떠한 차이가 있는지 알아보고자 하였다. 방법: 10 초와 5 분이라는 시간적 차이를 두어, 각각의 시간 경과 후 외현적 시연을 사용했을 경우와 그렇지 않은 경우에 대해 세 집단 간 수행력을 반응의 정확도와 오류유형의 두 가지 측면에서 비교 하였다. 그리고 대상자들의 수용, 표현어휘량과 새로운 음운표상인출 능력 간 상관관계를 분석하였다. 결과: 세 집단 간 시연 여부 및 지 연시간 정도에 따른 수행력 차이를 알아 본 결과, 단순언어장애 집단은 생활연령일치 집단보다 유의하게 수행력이 떨어졌으나 언어연령 일치 집단과는 그 차이가 유의하지 않았다. 세 집단 모두에서 시연 비동반 과제보다 동반 과제에서 수행력이 유의하게 좋았고, 10 초 후 에는 시연 비동반 과제와 동반 과제의 수행력에 차이 없었던 반면 5 분 후에는 시연 동반 과제의 수행력이 유의하게 좋았다. 단순언어장 애 집단은 다른 두 집단에 비해 음절생략, 단어오류, 무반응과 같은 오류유형을 유의하게 많이 보였다. 새로운 음운표상인출 능력은 수 용, 표현어휘량과 유의한 상관이 있는 것으로 분석되었다. 논의 및 결론: 외현적 시연이 일반 아동뿐 아니라 단순언어장애 아동의 음운 표상인출 능력 향상에 기여한다는 것을 확인하였다. 본 연구는 단어학습에 어려움을 보이는 언어장애 아동들의 치료 방향에 시사하는 바가 있을 것이다.

핵심어: 외현적 시연, 음운단기기억, 새로운 음운표상인출, 단순언어장애, 단어학습

본 연구는 2014학년도 대구대학교 학술연구비 지원에 의하여 연구되었음(20140304).

\section{참고문헌}

김나연, 하지완(2014). 조음음운장애아동과 일반아동의 음운표상의 질과 음운표상 부호화능력 비교. 언어청각장애연구, 19, 226-237.

김영태, 신문자(2004). 우리말 조음음운평가(U-TAP). 서울: 학지사.

김영태, 홍경훈, 김경희, 장혜성, 이주연(2009). 수용·표현어휘력검사(REVT). 서울: 서울장애인종합복지관.

김흥규, 강범모(1997). 한글 사용빈도의 분석. 서울: 고려대학교 민족문화연구원.

문수백, 변창진(1997). K-ABC 교육·심리측정도구(Korean-Kaufman Assessment Battery for Children: K-ABC). 서울: 학지사.

배세령, 하지완, 구민모, 황유미, 편성범(2016). 말소리장애아동의 새로운 음운표상 형성 능력. 언어청각장애연구, 21, 24-36.

신유나(2016). 주의분산에 따른 말소리장애 아동과 일반아동의 자음정확도 비교. 대구대학교대학원 석사학위청구논문.

이석정, 하지완, 구민모, 황유미, 편성범(2016). 6, 7세 아동의 시연조건에 따른 지연 비단어따라말하기 능력 비교. 언어청각장애연구, 21, 69-83.

조남호(2002). 현대 한국어 사용 빈도. 서울: 국립국어연구원.

한민지(2012). 구두 반복 학습 전략과 음운 단기 기억 능력이 한국어 어휘 학습에 미치는 영향. 이화여자대학교대학원 석사학위논문. 